\title{
Maternal exposure to nanosized titanium dioxide suppresses embryonic development in mice
}

\author{
This article was published in the following Dove Press journal: \\ International Journal of Nanomedicine \\ 24 August 2017 \\ Number of times this article has been viewed
}

\author{
Fashui Hong ${ }^{1-4}$ \\ Yingjun Zhoul-4 \\ Xiaoyang Zhao ${ }^{5}$ \\ Lei Sheng ${ }^{5}$ \\ Ling Wang ${ }^{6}$
}

'Jiangsu Collaborative Innovation Center of Regional Modern

Agriculture and Environmental Protection, ${ }^{2}$ Jiangsu Key Laboratory for Food Safety and Nutritional Function, ${ }^{3}$ Jiangsu Key Laboratory for Eco-Agricultural Biotechnology around Hongze Lake, ${ }^{4} \mathrm{School}$ of Life Sciences, Huaiyin Normal University, Huaian, ${ }^{5}$ Medical College of Soochow University, Suzhou, ${ }^{6}$ Library of Soochow University, Suzhou, Jiangsu, China
Correspondence: Fashui Hong Jiangsu Collaborative Innovation Center of Regional Modern Agriculture and Environmental Protection, Huaiyin Normal University, Changjiang

West Road No III, Huaian

223300, Jiangsu, China

Email hfshui666@I26.com

\begin{abstract}
Although nanoscale titanium dioxide (nano- $\mathrm{TiO}_{2}$ ) has been extensively used in industrial food applications and daily products for pregnant women, infants, and children, its potential toxicity on fetal development has been rarely studied. The main objective of this investigation was to establish the effects of maternal exposure of nano- $\mathrm{TiO}_{2}$ on developing embryos. Female imprinting control region mice were orally administered nano- $\mathrm{TiO}_{2}$ from gestational day 0 to 17 . Our findings showed that $\mathrm{Ti}$ concentrations in maternal serum, placenta, and fetus were increased in nano- $\mathrm{TiO}_{2}$-exposed mice when compared to controls, which resulted in reductions in the contents of calcium and zinc in maternal serum, placenta, and fetus, maternal weight gain, placental weight, fetal weight, number of live fetuses, and fetal crown-rump length as well as cauda length, and caused an increase in the number of both dead fetuses and resorptions. Furthermore, maternal nano- $\mathrm{TiO}_{2}$ exposure inhibited development of the fetal skeleton, suggesting a significant absence of cartilage, reduced or absent ossification, and an increase in the number of fetuses with dysplasia, including exencephaly, spina bifida, coiled tail, scoliosis, rib absence, and sternum absence. These findings indicated that nano$\mathrm{TiO}_{2}$ can cross the blood-fetal barrier and placental barrier, thereby delaying the development of fetal mice and inducing skeletal malformation. These factors may be associated with reductions in both calcium and zinc in maternal serum and the fetus, and both the placenta and embryos may be major targets of developmental toxicity following maternal exposure to nano- $\mathrm{TiO}_{2}$ during the prenatal period. Therefore, the application of nano- $\mathrm{TiO}_{2}$ should be carried out with caution.
\end{abstract}

Keywords: nanosized titanium dioxide, maternal exposure, embryonic toxicity, skeleton developmental suppression

\section{Introduction}

Nanoscale titanium dioxide (nano- $\mathrm{TiO}_{2}$ ) is widely used in various applications, including industry, medicine, and in consumer products such as cosmetics, sunscreens, food products, toothpaste, and sterilization and environmental control measures. ${ }^{1-6}$ Initially, nano- $\mathrm{TiO}_{2}$ was thought to exhibit relatively low toxicity as compared with other nanomaterials. ${ }^{7-10}$ However, numerous studies have suggested that following exposure via various routes including inhalation, injection, dermal deposition, and gastrointestinal tract absorption, nano- $\mathrm{TiO}_{2}$ can be found in various organs including the lung, liver, kidney, spleen, thymus, heart, stomach, brain, ovary, and testis potentially inducing toxic effects. ${ }^{11-13}$ Thus, based on a recent assessment, the International Agency for Research on Cancer has classified $\mathrm{TiO}_{2}$ as a human group $2 \mathrm{~B}$ carcinogen. ${ }^{14}$ Despite the fact that increased use and production of nano- $\mathrm{TiO}_{2}$ may result in health impacts due to its various uses, there is still a lack of knowledge regarding the adverse effects of nano- $\mathrm{TiO}_{2}$ on pregnant dams and embryo-fetal development.

It is known that the development of humans and animals, in particular developing embryos, is significantly influenced by environmental factors. ${ }^{15,16}$ The ability to scavenge 
toxins in the body is low as the developing embryo lacks the feedback protection mechanism, ${ }^{17,18}$ and may be more sensitive to the effects of nano- $\mathrm{TiO}_{2}$ compared with mature organisms. Recently, maternal exposure to manufactured nanoparticles (NPs) which induced toxicity during embryo development has attracted considerable attention. ${ }^{19,20}$ It was reported that maternal exposure to a variety of manufactured NPs was associated with harmful effects on mouse and rat embryos. ${ }^{21-25}$ NPs were detected in prenatally exposed offspring thereby indicating that NPs were transferred to the developing conceptus across the placenta. However, nano$\mathrm{CdO}$ was detected in the placenta and maternal organs of treated mice but not in their fetuses. ${ }^{26-28}$ Exposure of pregnant female mice or rats to different types of NPs may result in a variety of adverse pregnancy outcomes such as embryo mortality, intrauterine growth retardation, and structural anomalies in the prenatally exposed offspring, ${ }^{19}$ as developmentally toxic NPs crossed the placenta, embryos were directly exposed, and the embryotoxic effects of NPs seemed to have been secondary to maternal and/or placental toxicity. ${ }^{24}$ Philbrook et al indicated that the intragastric administration of hydroxyl-modified single-walled carbon nanotubes to pregnant mice resulted in increased skeletal defects, such as forked cervical vertebrae, reduced ossification of sternebrae and phalanges, and morphological abnormalities. ${ }^{29}$ It was proved that exposure to nanosilica $(70 \mathrm{~nm})$ led to fetal resorption and inhibition of fetal growth. ${ }^{30}$ Pregnant female rats were orally treated with nano zinc oxide $(\mathrm{ZnO})$ for 15 days, during gestational days (GDs) 5-19, at doses of 100, 200, and $400 \mathrm{mg} / \mathrm{kg} / \mathrm{day}$, and it was found that nano $\mathrm{ZnO}$ had no impact on embryo-fetal development in rats. ${ }^{31}$ Following maternal exposure to nano- $\mathrm{TiO}_{2}$, it was demonstrated that nano- $\mathrm{TiO}_{2}$ migrated into the uterus, affected the embryo, and caused abortion; for example, $500 \mathrm{mg} / \mathrm{kg}$ led to significant decreases in the total length of limb buds, arm skin thickness, number of proliferating chondrocytes in the arm, red blood cells in the fingers, and mesenchymal cells in the palm and wrist. ${ }^{32,33}$ Maternal exposure to nano- $\mathrm{TiO}_{2}$ was also reported to affect the development and function of the central nervous system in mouse and rat offspring. ${ }^{34-40}$ Therefore, we hypothesized that maternal exposure to nano- $\mathrm{TiO}_{2}$ may lead to disorders in embryo-fetal development, especially fetal bone development.

Accordingly, we determined whether mouse embryonic development was influenced by the toxic effects of nano$\mathrm{TiO}_{2}$ as there is evidence to suggest that fetuses are affected more than adults by a variety of environmental toxins, due to physiological immaturity. Female imprinting control region (ICR) mice were selected as the experimental model and exposed to nano- $\mathrm{TiO}_{2}$ via oral (gavage) administration from GD 0 to 17. After the 18-day gestational period, Ti, $\mathrm{Ca}$, and $\mathrm{Zn}$ contents in maternal serum, placenta, and fetus, maternal weight gain, fetal crown-rump and cauda length, body weight (BW) and placental weight, and numbers of live fetuses, dead fetuses, and resorption sites as well as fetal bone development were examined following maternal nano$\mathrm{TiO}_{2}$ exposure, with a view to clarifying its toxic effects on developing mouse embryos.

\section{Methods \\ Chemicals}

Nanoparticulate $\mathrm{TiO}_{2}$ was prepared by controlled hydrolysis of titanium tetrabutoxide. Details of the synthesis and characterization of nano- $\mathrm{TiO}_{2}$ are described in a previous report by our group. ${ }^{41} \mathrm{NP}$ characteristics were as follows: anatase phase, $6.5 \mathrm{~nm}$ particle size, mainly $294 \mathrm{~nm}$ hydrodynamic diameter, $174.8 \mathrm{~m}^{2} / \mathrm{g}$ surface area, and $7.57 \mathrm{mV}$ zeta potential. $^{41}$

\section{Ethics approval}

All animal experiments were conducted during the light phase of the light-dark cycle and approved by the Animal Experimental Committee of Soochow University (grant 2111270). Procedures were performed in accordance with the National Institutes of Health Guidelines for the Care and Use of Laboratory Animals.

\section{Animals and treatment}

Female CD-1 (ICR) mice (20 $\pm 1.5 \mathrm{~g})$ and male mice (23 $\pm 2 \mathrm{~g}$ ) were purchased from the Animal Center of Soochow University (China). All mice were housed in stainless steel cages in a ventilated animal room. The room temperature of the housing facility was maintained at $20^{\circ} \mathrm{C}-25^{\circ} \mathrm{C}$ with a relative humidity of $45 \%-55 \%$ and a 12 -hour light/dark cycle. Distilled water and sterilized food were available ad libitum. Prior to dosing, the mice were acclimated to the environment for 5 days. Mice were kept in cages at a ratio of 2:1 (female:male) from 18:00 every evening, and the vaginal suppository of female mice was checked the next morning at 06:00-08:00. Female mice were considered pregnant when the vaginal suppository was found (day 0). Twenty pregnant mice were randomly divided into four subgroups ( $\mathrm{n}=5$ per group), including a control group treated with $0.5 \% \mathrm{w} / \mathrm{v}$ hydroxypropylmethylcellulose (Sigma-Aldrich Co., St Louis, MO, USA) and three experimental groups treated with 25,50 , and $100 \mathrm{mg} / \mathrm{kg}$ $\mathrm{BW}$ nano- $\mathrm{TiO}_{2}$. For appropriate dose selection, previous reports were consulted. ${ }^{42,43}$ A report by the World Health 
Organization from 1969 was also consulted, and according to this report, the lethal dose 50 of $\mathrm{TiO}_{2}$ for rats was found to be $>12 \mathrm{~g} / \mathrm{kg}$ BW after oral administration. In addition, US Food and Drug Administration states that the quantity of nano-TiO 2 should not exceed $1 \%$ by weight of the food. Animals received 25, 50, and $100 \mathrm{mg} / \mathrm{kg} \mathrm{BW}$ nano- $\mathrm{TiO}_{2}$ orally (gavage) from GD 0 to 17 in an isolated animal room under specific pathogen-free conditions. After the 18-day gestational period, all pregnant mice were weighed and then sacrificed after being anesthetized with ether. Blood samples were collected from the eye vein by rapidly removing the eyeball. Serum was collected by centrifuging blood at $1,200 \times g$ for 10 minutes. The uterus was quickly removed, the numbers of live fetuses, dead fetuses, and resorption sites were counted and recorded for each litter, the weight of live fetuses in each litter was recorded, and the length of the fetal crown-rump and cauda were measured. Every effort was made to minimize animal suffering. All experiments were performed in accordance with the National Institutes of Health Guidelines for the Care and Use of Laboratory Animals.

\section{Element content analysis}

Two milliliters of maternal sera and $\sim 0.1 \mathrm{~g}$ of the placenta and the fetuses were digested, and analyzed for element contents. Inductively coupled plasma-mass spectrometry (Thermo Elemental X7; Thermo Electron Co, Waltham, MA, USA) was used to analyze the $\mathrm{Ti}, \mathrm{Ca}$, and $\mathrm{Zn}$ concentrations in the samples. ${ }^{42,43}$ An indium concentration of $20 \mathrm{ng} / \mathrm{mL}$ was used as an internal standard, and the detection limit of Ti was $0.074 \mathrm{ng} / \mathrm{mL}$.

\section{Evaluation of fetal skeleton development}

The skeletal development of fetuses was evaluated using Menegola's method. ${ }^{44}$ The selected fetal mice were soaked in hot water at $80^{\circ} \mathrm{C}$ for 10 seconds, the skin and viscera were carefully removed with eye forceps and scissors, and stained with alcian blue dye solution for 48 hours. The cartilage in the specimen appeared blue (slightly deeper than the color of the stain solution) when viewed with a stereo microscope (Olympus SZ61; Olympus Corporation, Tokyo, Japan) during the staining period; the specimen was then rinsed 2-3 times with tap water, immersed in alizarin red dye solution for 36-48 hours; the solution was renewed every 12 hours until the bone was purple, and thereafter again the specimen was gently rinsed 2-3 times with tap water. The double stained fetuses were placed in a new transparent solution containing $1 \%$ potassium hydroxide for 36-48 hours. ${ }^{45,46}$ The blue embryonic cartilage and purplish red skeletal ossification were observed under the stereo microscope.

\section{Statistical analysis}

Data were analyzed using Statistical Analysis Software (SAS 9.1) (Chicago, IL, USA). The significance of the differential expression between groups was assessed using one-way analysis of variance (ANOVA) followed by Tukey's honestly significant difference post hoc test, and the results are presented as means \pm standard deviation. Differences were considered statistically significant at $p<0.05$.

\section{Results}

\section{Element contents in maternal serum and fetuses}

In order to confirm whether nano- $\mathrm{TiO}_{2}$ entered the blood circulation in pregnant mice and crossed the blood-fetal barrier to enter the fetus, we observed and found significant increases in the Ti contents in the maternal serum, placenta, and fetus (Table $1, p<0.05$ ). Furthermore, to

Table I Effects of nano- $\mathrm{TiO}_{2}$ on element contents in maternal serum, placenta, and fetus

\begin{tabular}{|c|c|c|c|c|c|}
\hline & \multirow[t]{2}{*}{ Index } & \multicolumn{4}{|c|}{$\mathrm{Nano}^{-\mathrm{TiO}_{2}}$ (mg/kg BW) } \\
\hline & & 0 & 25 & 50 & 100 \\
\hline \multirow[t]{3}{*}{ Maternal serum } & Ti (ng/mL) & $0.05 \pm 0.00$ & $\mathrm{I} .5 \mathrm{I} \pm 0.04^{* * *}$ & $2.06 \pm 0.07 * * *$ & $3.25 \pm 0.09 * * *$ \\
\hline & $\mathrm{Ca}(\mu \mathrm{g} / \mathrm{mL})$ & $|57.8| \pm 7.1 \mid$ & $148.73 \pm 8.95$ & $|36.87 \pm 6.2|^{*}$ & $129.86 \pm 5.59 *$ \\
\hline & $\mathrm{Zn}(\mu \mathrm{g} / \mathrm{mL})$ & $1.71 \pm 0.06$ & $1.63 \pm 0.04$ & $\mathrm{I} .5 \mathrm{I} \pm 0.05^{*}$ & $1.46 \pm 0.03 *$ \\
\hline \multirow[t]{3}{*}{ Placenta } & $\mathrm{Ti}$ (ng/g placenta) & $0.08 \pm 0.00$ & $15.98 \pm 1.06^{* * *}$ & $22.03 \pm 1.73 * * *$ & $35.07 \pm 2.31 * * *$ \\
\hline & Ca ( $\mu g /$ placenta $)$ & $302.27 \pm 13.79$ & $250.13 \pm 8.22 *$ & $176.42 \pm 1.29 * * *$ & $163.51 \pm 1.7 \mid * * *$ \\
\hline & Zn ( $\mu g /$ placenta) & $109.35 \pm 5.3 \mid$ & $98.28 \pm 7.05$ & $59.61 \pm 2.15^{* *}$ & $52.76 \pm 1.53 * *$ \\
\hline \multirow[t]{3}{*}{ Fetus } & $\mathrm{Ti}$ (ng/g fetus) & $0.0 I \pm 0.00$ & $10.25 \pm 0.35^{* * *}$ & $14.59 \pm 0.89 * * *$ & $21.53 \pm 0.72 * * *$ \\
\hline & $\mathrm{Ca}(\mu \mathrm{g} /$ fetus $)$ & $246.13 \pm 8.95$ & $232.22 \pm 6.66$ & $2 \mid 4.6 I \pm 8.12 *$ & $205.79 \pm 7.53 *$ \\
\hline & $\mathrm{Zn}(\mu \mathrm{g} /$ fetus) & $85.6 I \pm 3.35$ & $80.36 \pm 2.71$ & $70.66 \pm 1.89 *$ & $65.17 \pm 2.34^{*}$ \\
\hline
\end{tabular}

Notes: Results marked with an asterisk, double asterisks, or three asterisks mean they are significantly different from the control (no nano-TiO $)^{\text {) at }}$ the $p<0.05, p<0.0$ I, and $p<0.00$ I confidence level, respectively. Values represent mean \pm SD $(n=5)$.

Abbreviations: nano- $\mathrm{TiO}_{2}$, nanoscale titanium dioxide; $\mathrm{BW}$, body weight; SD, standard deviation. 
Table 2 Effects of nano- $\mathrm{TiO}_{2}$ on maternal weight (g) gain during pregnancy

\begin{tabular}{|c|c|c|c|c|}
\hline \multirow{2}{*}{$\begin{array}{l}\text { Day of } \\
\text { pregnancy }\end{array}$} & \multicolumn{4}{|c|}{$\mathrm{Nano}^{-\mathrm{TiO}_{2}}(\mathrm{mg} / \mathrm{kg} \mathrm{BW})$} \\
\hline & 0 & 25 & 50 & 100 \\
\hline 0 & $27.62 \pm 1.04$ & $27.13 \pm 1.15$ & $26.98 \pm 1.06$ & $27.46 \pm 0.92$ \\
\hline 3 & $28.96 \pm 1.01$ & $28.65 \pm 1.13$ & $28.55 \pm 1.12$ & $28.91 \pm 0.82$ \\
\hline 6 & $31.35 \pm 1.15$ & $31.27 \pm 1.22$ & $31.08 \pm 1.05$ & $31.12 \pm 1.06$ \\
\hline 9 & $34.5 I \pm 1.23$ & $34.08 \pm 1.19$ & $33.95 \pm 1.29$ & $33.32 \pm 1.18$ \\
\hline 12 & $42.98 \pm 1.57$ & $42.08 \pm 0.99$ & $41.45 \pm 1.55$ & $40.77 \pm 13.2$ \\
\hline 15 & $53.69 \pm 2.06$ & $51.58 \pm 1.18$ & $51.09 \pm 1.71$ & $48.96 \pm 1.28 *$ \\
\hline 18 & $64.7| \pm 2.5|$ & $60.11 \pm 2.07 *$ & $59.32 \pm 2.14 *$ & $56.79 \pm 2.15^{*}$ \\
\hline
\end{tabular}

Notes: Results marked with an asterisk mean that they are significantly different from the control (no nano- $\mathrm{TiO}_{2}$ ) at the $p<0.05$ confidence level. Values represent mean $\pm S D(n=5)$.

Abbreviations: nano- $\mathrm{TiO}_{2}$, nanoscale titanium dioxide; BW, body weight; SD, standard deviation.

confirm the effects of maternal exposure to nano- $\mathrm{TiO}_{2}$ on embryonic development, we also examined the changes in $\mathrm{Ca}$ and $\mathrm{Zn}$ contents in maternal serum, placenta, and fetus, and found that the contents of $\mathrm{Ca}$ and $\mathrm{Zn}$ decreased significantly in the high dose nano- $\mathrm{TiO}_{2}$-treated groups (Table $1, p<0.05$ ).

\section{Maternal weight gain}

Pregnant mice were exposed to different concentrations of nano- $\mathrm{TiO}_{2}$ from GD 0 to 17 , and the weight of pregnant mice at days $0,3,9,12,15$, and 18 during pregnancy is presented in Table 2. It can be seen that maternal weight gain gradually increased with pregnancy duration in the control group and nano- $\mathrm{TiO}_{2}$ groups, whereas maternal weight gain in the nano- $\mathrm{TiO}_{2}$-exposed groups at day 18 was significantly lower than that of the control (Table 2, $p<0.05$ ).

\section{Fetal growth}

Pregnant mice were sacrificed at GD 18, and the cesarean section was performed to measure the crown-rump and cauda length, and fetal BW and placental weight of the live fetal mice (Table 3). Compared with the control, both fetal crownrump and cauda length, and fetal $\mathrm{BW}$ and placental weight in the $100 \mathrm{mg} / \mathrm{kg}$ nano- $\mathrm{TiO}_{2}$-treated group were markedly lower than that in the control (Table 3, $p<0.05$ ).

\section{Survival and mortality of fetuses}

After GD 18, the numbers of live, dead, and resorption sites were counted and are shown in Table 4. Compared with the control, the number of live fetuses in the $100 \mathrm{mg} / \mathrm{kg}$ nano- $\mathrm{TiO}_{2}$-treated group was significantly lower than that in the control, whereas the numbers of dead fetuses and resorption sites were obviously higher than those in the control (Table 4, $p<0.05$ ), respectively.

\section{Fetal skeletal development}

Table 5 and Figure 1 show that fetal skeleton development in the $100 \mathrm{mg} / \mathrm{kg}$ nano- $\mathrm{TiO}_{2}$-exposed group was significantly slower than that in the control, suggesting the absence of significant cartilage, non-ossification of the sternum and metacarpal bones, or incomplete ossification of the sternum. Following maternal exposure to nano- $\mathrm{TiO}_{2}$, fetal dysplasia was also observed compared with the control; dysplasia included exencephaly, spina bifida, coiled tail, scoliosis, rib absence, and sternum absence.

\section{Discussion}

Recently, knowledge on the toxicity of different types of nano- $\mathrm{TiO}_{2}$, including damage to the liver, lung, kidney, spleen, heart, brain, testis, and ovary of mice or rats, ${ }^{11}$ stomach and thymus of mice, ${ }^{12,13}$ inflammatory response, membrane injury, and cytotoxicity, ${ }^{11}$ has increased, resulting in several toxicity studies of nano- $\mathrm{TiO}_{2}$ in different biological systems, such as zebrafish and Caenorhabditis elegans. ${ }^{47,48}$ However, evidence of developmental toxicity caused by nano- $\mathrm{TiO}_{2}$ in mammals is still limited. It is highly desirable and necessary to have a better understanding of the possible developmental toxicity of nano- $\mathrm{TiO}_{2}$ as humans are often exposed to nano- $\mathrm{TiO}_{2}$ both intentionally and unintentionally.

This study was conducted to examine the maternal and developmental toxic potential of nano- $\mathrm{TiO}_{2}$ orally

Table 3 Effects of nano- $\mathrm{TiO}_{2}$ on fetal growth of mice

\begin{tabular}{|c|c|c|c|c|}
\hline \multirow[t]{2}{*}{ Index } & \multicolumn{4}{|c|}{ Nano-TiO $_{2}(\mathrm{mg} / \mathrm{kg}$ BW$)$} \\
\hline & 0 & 25 & 50 & 100 \\
\hline Fetal crown-rump length $(\mathrm{cm})$ & $2.42 \pm 0.11$ & $2.16 \pm 0.13^{*}$ & $1.73 \pm 0.08 * *$ & $1.59 \pm 0.09 * *$ \\
\hline Fetal cauda length $(\mathrm{cm})$ & $0.77 \pm 0.03$ & $0.76 \pm 0.02$ & $0.56 \pm 0.02 *$ & $0.49 \pm 0.01 * *$ \\
\hline Fetal body weight (g) & $1.35 \pm 0.04$ & $1.37 \pm 0.03$ & $1.31 \pm 0.03$ & $1.24 \pm 0.02^{*}$ \\
\hline Placental weight (mg) & $105.23 \pm 4.15$ & $98.08 \pm 4.32$ & $81.08 \pm 1.17^{*}$ & $80.16 \pm 2.53^{*}$ \\
\hline
\end{tabular}

Notes: Results marked with an asterisk or double asterisks mean they are significantly different from the control (no nano- $\mathrm{TiO}_{2}$ ) at the $p<0.05$ and $p<0.01$ confidence level. Values represent mean $\pm S D(n=5)$.

Abbreviations: nano- $\mathrm{TiO}_{2}$, nanoscale titanium dioxide; $\mathrm{BW}$, body weight; $\mathrm{SD}$, standard deviation. 
Table 4 Effects of nano- $\mathrm{TiO}_{2}$ on survival and mortality in mouse fetus

\begin{tabular}{lllll}
\hline Index & \multicolumn{2}{l}{ Nano-TiO $_{2}$ (mg/kg BW) } & & \\
\cline { 2 - 5 } & $\mathbf{0}$ & $\mathbf{2 5}$ & $\mathbf{5 0}$ & 100 \\
\hline Number of live fetuses & $12.98 \pm 0.39$ & $12.73 \pm 0.34$ & $11.89 \pm 0.31$ & $10.35 \pm 0.36 *$ \\
Number of dead fetuses & $0.29 \pm 0.01$ & $0.31 \pm 0.01$ & $0.51 \pm 0.02 * *$ & $0.55 \pm 0.01 * *$ \\
Number of resorption sites & $0.41 \pm 0.02$ & $0.43 \pm 0.01$ & $1.32 \pm 0.04 * *$ & $1.39 \pm 0.04 * *$ \\
\hline
\end{tabular}

Notes: Results marked with an asterisk or double asterisks mean they are significantly different from the control (no nano-TiO $)_{2}$ at the $p<0.05$ and $p<0.01$ confidence level. Values represent mean $\pm S D(n=5)$.

Abbreviations: nano- $\mathrm{TiO}_{2}$, nanoscale titanium dioxide; $\mathrm{BW}$, body weight; $\mathrm{SD}$, standard deviation.

administered to mice during GD 0-17 of pregnancy. Our findings showed that following maternal exposure, nano$\mathrm{TiO}_{2}$ crossed the blood-fetal barrier or placental barrier and was deposited in maternal serum, placenta, and fetus, leading to significant decreases in $\mathrm{Ca}$ and $\mathrm{Zn}$ in the maternal serum, placenta, and fetus. In addition, maternal exposure to $100 \mathrm{mg} / \mathrm{kg}$ nano- $\mathrm{TiO}_{2}$ markedly reduced maternal weight gain, placental weight, fetal weight, number of live fetuses, and fetal crown-rump length as well as cauda length, and increased the numbers of both dead fetuses and resorption sites. Skeletal development in fetal mice following maternal exposure to $100 \mathrm{mg} / \mathrm{kg}$ nano- $\mathrm{TiO}_{2}$ lagged behind that of the control group, and resulted in absent or reduced ossification, and fetal dysplasia. The main results of the present study are discussed subsequently.

Most of the skeletal system is derived from mesoderm, which is mainly from the ventral and medial mesenchyme of the segment. The critical period of fetal organ development in mice or rats is $7.5-18$ days. Therefore, the administration of drugs during this stage can be used to examine their effects on the organs of fetal mice or rats. In the study of embryonic developmental toxicity, evaluation of skeletal deformities is often a major part of the assessment of the effects of external compounds on the body, and bone development is often determined by bone staining. The bones of fetal mice are only partially ossified and cartilage is still present at GD 18. In the present study, we observed that fetal vertebrae, carpal, and metatarsophalangeal bones in the control showed uniform cartilage at GD 18. However, maternal exposure to nano- $\mathrm{TiO}_{2}$ resulted in retardation of skeletal development, for example, cartilage was absent, the ossification centers of some bones were absent, the scale of the ossification center was less than that in the control group, and skeletal deformities (such as scoliosis, vertebral fusion, rib deformity) occurred.

The suppression of embryonic bone development and skeletal abnormalities in fetuses caused by nano- $\mathrm{TiO}_{2}$ may be related to the following factors. 1) The placenta is one of the target organs of nano- $\mathrm{TiO}_{2}$; thus, nano- $\mathrm{TiO}_{2}$ can affect

Table 5 Effects of nano- $\mathrm{TiO}_{2}$ on skeletal ossification in mouse fetuses $(n=10)$

\begin{tabular}{|c|c|c|c|c|c|}
\hline & \multirow[t]{2}{*}{ Index } & \multicolumn{4}{|c|}{$\mathrm{Nano}^{-\mathrm{TiO}_{2}}$ (mg/kg BW) } \\
\hline & & 0 & 25 & 50 & 100 \\
\hline \multirow[t]{4}{*}{$\begin{array}{l}\text { Cranial } \\
\text { brain }\end{array}$} & Frontal bone & Obvious ossification & Lamellar ossification & Lamellar ossification & $\begin{array}{l}\text { Small and reticulate } \\
\text { ossification }\end{array}$ \\
\hline & Parietal bone & Most ossification & Incomplete ossification & $\begin{array}{l}\text { Small and reticulate } \\
\text { ossification }\end{array}$ & $\begin{array}{l}\text { Incomplete ossification; or } \\
\text { unossified }\end{array}$ \\
\hline & Occipital bone & $\begin{array}{l}\text { Ossification of } \\
\text { the base, occipital } \\
\text { condyle, and squama }\end{array}$ & $\begin{array}{l}\text { Ossification of the base and } \\
\text { occipital condyle; incomplete } \\
\text { partial squamous ossification }\end{array}$ & $\begin{array}{l}\text { Condylar ossification, } \\
\text { incomplete ossification } \\
\text { of the base }\end{array}$ & Condylar ossification \\
\hline & Nasal bone & Ossification & Ossification & Ossification & Small extent of ossification \\
\hline \multirow[t]{2}{*}{$\begin{array}{l}\text { Pharyngeal } \\
\text { skull }\end{array}$} & Maxillary bone & Ossification & Small extent of ossification & Punctate ossification & $\begin{array}{l}\text { Discontinuous } \\
\text { ossification }\end{array}$ \\
\hline & Mandible & Ossification & Ossification & Ossification & Partial ossification \\
\hline \multirow[t]{2}{*}{ Axial bone } & Vertebrae & $\begin{array}{l}\text { Ossification of the } \\
\text { cervical, sacral, and } \\
\text { thoracolumbar arches }\end{array}$ & $\begin{array}{l}\text { Ossification of the neck, sacrum, } \\
\text { and part of the thoracolumbar } \\
\text { arches }\end{array}$ & $\begin{array}{l}\text { Ossification of the cervical, } \\
\text { sacral, and lumbar arches }\end{array}$ & Thoracolumbar ossification \\
\hline & Rib & Ossification & Ossification & Ossification & Ossification \\
\hline Limb bone & & $\begin{array}{l}\text { Ossification from } \\
\text { limb to phalanx }\end{array}$ & $\begin{array}{l}\text { Ossification from limb to } \\
\text { metatarsal bone }\end{array}$ & $\begin{array}{l}\text { Small extent of ossification } \\
\text { from limb to metatarsal bone }\end{array}$ & $\begin{array}{l}\text { Small extent of ossification } \\
\text { from limb to metatarsal bone }\end{array}$ \\
\hline
\end{tabular}

Abbreviations: nano- $\mathrm{TiO}_{2}$, nanoscale titanium dioxide; $\mathrm{BW}$, body weight. 


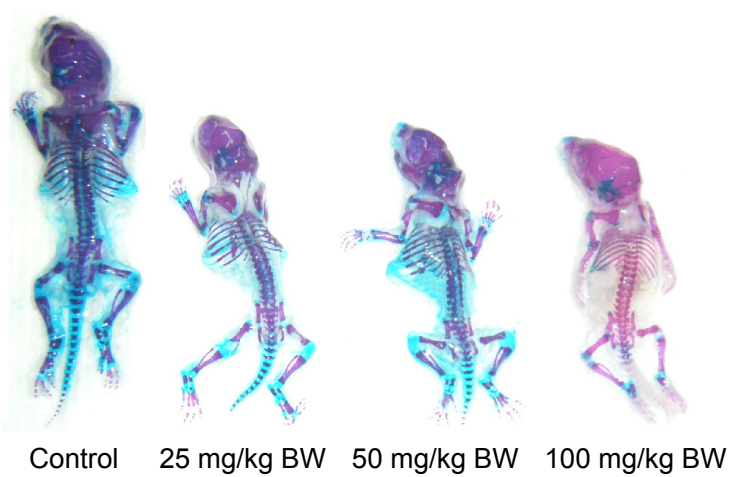

Figure I Maternal exposure to nano- $\mathrm{TiO}_{2}$ induced dysplasia of skeleton in mice embryos at gestational day 18.

Notes: Blue indicates cartilage. Purplish red indicates ossification. Red indicates incomplete ossification.

Abbreviations: nano- $\mathrm{TiO}_{2}$, nanoscale titanium dioxide; $\mathrm{BW}$, body weight.

the normal development of embryos by interfering with placental blood flow, substance transport, and endocrine as well as substance metabolism. In this study, we found that maternal exposure to nano- $\mathrm{TiO}_{2}$ not only caused intrauterine developmental retardation of the fetus, but also affected bone ossification, which may have been due to nano- $\mathrm{TiO}_{2}$ interfering with the permeability of $\mathrm{Ca}^{2+}$ in the placenta. Furthermore, we also observed that nano- $\mathrm{TiO}_{2}$ caused deformities including exencephaly, spina bifida, coiled tail, scoliosis, rib absence, and sternum absence. 2) $\mathrm{Nano}-\mathrm{TiO}_{2}$ reduced the levels of $\mathrm{Ca}$ in pregnant mice and fetuses, which may be an important aspect of nano- $\mathrm{TiO}_{2}$-induced toxicity. In general, the active transport of $\mathrm{Ca}$ by osteoblasts is broadly divided into three stages: firstly, $\mathrm{Ca}$ channels are open and $\mathrm{Ca}^{2+}$ enters the cells; secondly, $\mathrm{Ca}^{2+}$ binds to the $\mathrm{Ca}$ binding protein in the cytoplasm and rapidly spreads from the free surface side of the cell to the basal surface; finally, the Ca pump on the basal plane uses energy from the hydrolysis of ATP to pump $\mathrm{Ca}^{2+}$ from the cells to the extracellular region. ${ }^{49}$ Exposure to nano- $\mathrm{TiO}_{2}$ may decrease $\mathrm{Ca}$ absorption and increase excretion, leading to a negative $\mathrm{Ca}$ balance, and a subsequent reduction in Ca levels in the embryo. Ossification of bone, whether osteogenesis or $\mathrm{Ca}$ deposition of endochondral ossification, is an important step in bone formation. Our data suggested that maternal nano- $\mathrm{TiO}_{2}$ exposure interfered with $\mathrm{Ca}$ metabolism in embryos (Ca reductions in maternal serum, placenta, and fetus), and thus affected ossification in the fetus. Nano- $\mathrm{TiO}_{2}$ may bind to proteins on the cell membrane, thereby changing membrane function and signal transduction resulting in toxicity. The effects of nano- $\mathrm{TiO}_{2}$ on bone $\mathrm{Ca}$ included two aspects: on one hand, the inhibition of bone Ca deposition may lead to the formation of a barrier in the ossification center during bone development; ${ }^{49}$ on the other hand, damage to osteoblasts and chondrocytes, and increased osteoclast activity may result in an increase in bone Ca dissolution. ${ }^{50,51}$ 3) $\mathrm{Nano}^{-\mathrm{TiO}_{2}}$ reduced the levels of $\mathrm{Zn}$ in pregnant mice, placenta, and fetuses, which may also be an important aspect of nano- $\mathrm{TiO}_{2}$-induced toxicity. It has been shown that $\mathrm{Zn}$ is closely related to bone development, metabolism, and function during normal development of the embryo or fetus. ${ }^{52}$ Osteoblasts secrete organic substances, such as collagen and proteoglycan, which are called osteoids. Osteoblasts are gradually embedded by osteoids and become osteocytes. Serum phosphatase (AKP) is a marker of osteoblasts, and catalyzes the decomposition of phosphate compounds to produce free phosphates that combine with $\mathrm{Ca}$ in the intercellular substance to form $\mathrm{Ca}$ phosphate, which is involved in the regulation of calcification. AKP is a $\mathrm{Zn}$-dependent enzyme. $\mathrm{Zn}$ can stabilize AKP conformation and maintain AKP activity. When $\mathrm{Zn}$ is deficient, the conformation and function of AKP are compromised. Epidemiological findings suggest that $\mathrm{Zn}$ deficiency delays growth and bone age in animals and humans; a severe lack of $\mathrm{Zn}$ in animals can cause skeletal deformities. ${ }^{53} \mathrm{Nano}^{-\mathrm{TiO}_{2}}$ may play a direct role as a promoter of the metallothionein (MT) gene, and induce MT synthesis in maternal liver, kidney, and in placental trophoblast cells. MT rapidly combines with $\mathrm{Zn}^{2+}$, and then decreases the $\mathrm{Zn}$ concentration in maternal blood and impairs placental $\mathrm{Zn}^{2+}$ transport, which results in an insufficient supply of $\mathrm{Zn}$ to the embryo, leading to a slow ossification center or incomplete calcification of fetal bones. Exposure to nano- $\mathrm{TiO}_{2}$ has been demonstrated to increase MT level in fish and Daphnia. ${ }^{54,55}$ A previous study showed that exposure to $\mathrm{Cd}$ in pregnant rats caused significant reductions in maternal serum and fetal $\mathrm{Zn}$ levels. ${ }^{56}$ In addition, maternal $\mathrm{Zn}$ supplementation during pregnancy significantly decreased fetal malformations and growth retardation in mice caused by $\mathrm{Cd} .{ }^{57} \mathrm{In}$ the present study, the levels of $\mathrm{Zn}, \mathrm{Ca}$, and $\mathrm{Ti}$ in the maternal serum of control mice were determined by the contents of $\mathrm{Zn}, \mathrm{Ca}$, and $\mathrm{Ti}$ in the diet and drinking water, which were strictly controlled according to the standards of mouse rearing from the Animal Center of Soochow University (China) to meet the needs for growth and development of mice. These findings indicate that reductions of $\mathrm{Ca}$ and $\mathrm{Zn}$ in the maternal serum may be an important cause of nano- $\mathrm{TiO}_{2}$-induced growth retardation in fetal mice.

The placenta is an important link between the mother and the fetus, and has substance transport, barrier, and endocrine functions. In the current study, placental weight in the nano- $\mathrm{TiO}_{2}$-treated group was lower than that in the 
control group, suggesting that maternal nano- $\mathrm{TiO}_{2}$ exposure inhibited placental growth, which may be associated with decreases in the relative volume of placental villus space, the relative surface area of fetal capillaries, and the absolute volume of the placenta. ${ }^{58}$ Furthermore, our data suggested that nano- $\mathrm{TiO}_{2}$ content in the maternal blood was positively correlated with placental and fetal nano- $\mathrm{TiO}_{2}$ levels, and negatively correlated with placental and fetal weight. These findings indicate that placenta and embryo may be the second target organs of nano- $\mathrm{TiO}_{2}$ toxicity, and the abnormal development of placenta may be one of the causes of nano$\mathrm{TiO}_{2}$-induced fetal growth retardation. Taken together, these findings demonstrate that consecutively maternal exposure to nano- $\mathrm{TiO}_{2}$ could suppress embryonic development in mice; however, the underlying molecular mechanism requires further study.

\section{Conclusion}

In this experimental study, exposure to nano- $\mathrm{TiO}_{2}$ in pregnant mice caused fetal growth retardation, which was associated with embryonic toxicity and bone toxicity due to nano- $\mathrm{TiO}_{2}$ accumulation in fetal mice. These effects may be due to the direct role or the indirect role of nano- $\mathrm{TiO}_{2}$ interfering with $\mathrm{Ca}, \mathrm{Zn}$, and other metabolic processes, or may be the result of a combination of several factors, which require further investigation in the future. Therefore, the use of nano- $\mathrm{TiO}_{2}$ and exposure to nano- $\mathrm{TiO}_{2}$, especially during pregnancy in humans, should be thoroughly investigated.

\section{Acknowledgments}

This work was supported by the National Natural Science Foundation of China (grant nos 31671033, 81473007, 81273036, and 30901218), the National Natural Science Foundation of Jiangsu Province (grant no BK20161306), and the Top-notch Academic Programs Project of Jiangsu Higher Education Institutions (PPZY2015A018).

\section{Disclosure}

The authors report no conflicts of interest in this work.

\section{References}

1. Gelis C, Girard S, Mavon A, Delverdier M, Paillous N, Vicendo P. Assessment of the skin photoprotective capacities of an organomineral broad-spectrum sunblock on two ex vivo skin models. Photodermatol Photoimmunol Photomed. 2003;19:242-253.

2. Sahu KK, Alex TC, Mishra D, Agrawal A. An overview on the production of pigment grade titania from titania-rich slag. Waste Manag Res. 2006;24:74-79.

3. Shukla RK, Sharma V, Pandey AK, Singh S, Sultana S, Dhawan A. ROS mediated genotoxicity induced by titanium dioxide nanoparticles in human epidermal cells. Toxicol In Vitro. 2011;25:231-241.
4. Kaida T, Kobayashi K, Adachi M, Suzuki F. Optical characteristics of titanium oxide interference film and the film laminated with oxides and their applications for cosmetics. J Cosmet Sci. 2004;55: 219-220.

5. Chaudhry Q, Scotter M, Blackburn J, et al. Applications and implications of nanotechnologies for the food sector. Food Addit Contam Part A Chem Anal Control Expo Risk Assess. 2008;25:241-258.

6. Weir A, Westerhoff P, Fabricius L, Hristovski K, von Goetz N. Titanium dioxide nanoparticles in food and personal care products. Environ Sci Technol. 2012;46:2242-2250.

7. Jeng HA, Swanson J. Toxicity of metal oxide nanoparticles in mammalian cells. J Environ Sci Health A Tox Hazard Subst Environ Eng. 2006;41:2699-2711.

8. Mikkelsen L, Sheykhzade M, Jensen KA, et al. Modest effect on plaque progression and vasodilatory function in atherosclerosis-prone mice exposed to nanosized $\mathrm{TiO}_{2}$. Part Fibre Toxicol. 2011;8:32-48.

9. Zhao J, Bowman $\mathrm{L}$, Zhang $\mathrm{X}$, et al. Titanium dioxide $\left(\mathrm{TiO}_{2}\right)$ nanoparticles induce JB6 cell apoptosis through activation of the caspase-8/ Bid and mitochondrial pathways. J Toxicol Environ Health A. 2009; 72:1141-1149.

10. Madl AK, Pinkerton KE. Health effects of inhaled engineered and incidental nanoparticles. Crit Rev Toxicol. 2009;39:629-658.

11. Hong FS, Yu XH, Wu N, Zhang YQ. Progress of in vivo studies on the systemic toxicities induced by titanium dioxide nanoparticles. Toxicol Res. 2017;6:115-133.

12. Hong FS, Zhou YJ, Ji L, Chen T, Wang L. Gastric toxicity involving alterations of gastritis-related protein expression in mice following long-term exposure to nano $\mathrm{TiO}_{2}$. Food Res Int. 2017;95:38-45.

13. Hong FS, Zhou YM, Zhou YJ, Wang L. Immunotoxic effects of thymus in mice following exposure to nanoparticulate $\mathrm{TiO}_{2}$. Environ Toxicol. Epub 2017 Jun 24.

14. IARC (International Agency for Research on Cancer). Monographs on the evaluation of carcinogenic risks to humans: carbon black, titanium dioxide, and talc. Lyon, France: World Health Organization, International Agency for Research on Cancer; 2010:93.

15. Hayashi A, Nagaoka M, Yamada K, Ichitani Y, Miake Y, Okado N Maternal stress induces synaptic loss and developmental disabilities of offspring. Int J Dev Neurosci. 1998;16:209-216.

16. Iqbal U, Dringenberg HC, Brien JF, Reynolds JN. Chronic prenatal ethanol exposure alters hippocampal GABAA receptors and impairs spatial learning in the guinea pig. Behav Brain Res. 2004;150:117-125.

17. Anderson LM, Diwan BA, Fear NT, Roman E. Critical windows of exposure for children's health: cancer in human epidemiological studies and neoplasms in experimental animal models. Environ Health Perspect. 2000;108(Suppl 3):573-594.

18. Anderson LM. Predictive values of traditional animal bioassay studies for human perinatal carcinogenesis risk determination. Toxicol Appl Pharmacol. 2004;199(2):162-174.

19. Delgado IF, Paumgartten FR. Current challenges in toxicological research: evaluation of the developmental toxicity of manufactured nanomaterials. Vigilância Sanitária em Debate. 2013;1(4):11-24. Portuguese.

20. Sun JL, Zhang Q, Wang ZP, Yan B. Effects of nanotoxicity on female reproductivity and fetal development in animal models. Int J Mol Sci. 2013;14(5):9319-9337.

21. Pietroiusti A, Massimiani M, Fenoglio I, et al. Low doses of pristine and oxidized single-wall carbon nanotubes affect mammalian embryonic development. ACS Nano. 2011;5(6):4624-4633.

22. Hougaard KS, Jackson P, Jensen KA, et al. Effects of prenatal exposure to surface-coated nanosized titanium dioxide (UV-Titan). A study in mice. Part Fibre Toxicol. 2010;7:16.

23. Umezawa M, Tainaka H, Kawashima N, Shimizu M, Takeda K. Effect of fetal exposure to titanium dioxide nanoparticle on brain developmentbrain region information. J Toxicol Sci. 2012;37(6):1247-1252.

24. Blum JL, Xiong JQ, Hoffman C, Zelikoff JT. Cadmium associated with inhaled cadmium oxide nanoparticles impacts fetal and neonatal development and growth. Toxicol Sci. 2012;126(2):478-486. 
25. Chan WH, Shiao NH. Cytotoxic effect of CdSe quantum dots on mouse embryonic development. Acta Pharmacol Sin. 2008;29(2):259-266.

26. Tian X, Zhu M, Du L, et al. Intrauterine inflammation increases maternofetal transfer of gold nanoparticles in a size-dependent manner in murine pregnancy. Small. 2013;9(14):2432-2439.

27. Jo E, Seo G, Kwon JT, et al. Exposure to zinc oxide nanoparticles affects reproductive development and biodistribution in offspring rats. J Toxicol Sci. 2013;38(4):525-530.

28. Chu M, Wu Q, Yang H, et al. Transfer of quantum dots from pregnant mice to pups across the placental barrier. Small. 2010;6(5):670-678.

29. Philbrook NA, Walker VK, Afrooz ARMN, Saleh NB, Winn LM. Investigating the effects of functionalized carbon nanotubes on reproduction and development in Drosophila melanogaster and CD-1 mice. Reprod Toxicol. 2011;32:442-448.

30. Yamashita K, Yoshioka Y. [Safety assessment of nanomaterials in reproductive developmental field]. Yakugaku Zasshi. 2012;132(3):331-335. Japanese.

31. Hong JS, Park MK, Kim MS, et al. Effect of zinc oxide nanoparticles on dams and embryo-fetal development in rats. Int J Nanomedicine. 2014;9(Suppl 2):145-157.

32. Roodbari NH, Parivar K, Badiei B, Barogh SZ. Cytotoxic effects of nano-titanium dioxide on forelimb bud development in NMRI mouse embryos in vivo. Zums J. 2014;22(91):11-24.

33. Parivar K, Hayati Rudbari N, Khanbabaee R, Khaleghi M. The effect of nano-titanium dioxide on limb bud development of NMRI mouse embryo in vivo. Cell J. 2015;17(2):296-303.

34. Shimizu M, Tainaka H, Oba T, Mizuo K, Umezawa M, Takeda K. Maternal exposure to nanoparticulate titanium dioxide during the prenatal period alters gene expression related to brain development in the mouse. Part Fibre Toxicol. 2009;6:20.

35. Takeda K, Suzuki KI, Ishihara A, et al. Nanoparticles transferred from pregnant mice to their offspring can damage the genital and cranial nerve systems. J Health Sci. 2009;55(1):95-102.

36. Takahashi Y, Shinkai Y, Mizuo K, Oshio S, Takeda K. Prenatal exposure to titanium dioxide nanoparticles increases dopamine levels in the prefrontal cortex and neostriatum of mice. J Toxicol Sci. 2010; 35(5):749-756.

37. Mohammadipour A, Hosseini M, Fazel A, et al. The effects of exposure to titanium dioxide nanoparticles during lactation period on learning and memory of rat offspring. Toxicol Ind Health. 2016;32(2):221-228.

38. Mohammadipour A, Fazel A, Haghir H, et al. Maternal exposure to titanium dioxide nanoparticles during pregnancy; impaired memory and decreased hippocampal cell proliferation in rat offspring. Environ Toxicol Pharmacol. 2014;37:617-625.

39. Gao X, Yin S, Tang M, Chen J, Yang Z, Zhang W. Effects of developmental exposure to $\mathrm{TiO}_{2}$ nanoparticles on synaptic plasticity in hippocampal dentate gyrus area: an in vivo study in anesthetized rats. Biol Trace Elem Res. 2011;143(3):1616-1628.

40. Cui YH, Chen XY, Zhu Z, et al. Prenatal exposure to nanoparticulate titanium dioxide enhances depressive-like behaviors in adult rats. Chemosphere. 2014;96:99-104.

41. Hu RP, Zheng L, Zhang T, et al. Molecular mechanism of hippocampal apoptosis of mice following exposure to titanium dioxide nanoparticles. J Hazard Mater. 2011;191:32-40.
42. Gao GD, Ze YG, Li B, et al. Ovarian dysfunction and gene-expressed characteristics of female mice caused by long-term exposure to titanium dioxide nanoparticles. J Hazard Mater. 2012;243:19-27.

43. Gao GD, Ze YG, Zhao XY, et al. Titanium dioxide nanoparticleinduced testicular damage, spermatogenesis suppression, and gene expression alterations in male mice. J Hazard Mater. 2013;258-259: 133-143.

44. Menegola E, Broccia ML, Di Renzo F, Giavini E. Comparative study of sodium valproate-induced skeletal malformations using single or double staining methods. Reprod Toxicol. 2002;16(6):815-823.

45. Luo C, Ren RN, Hu YH, Chen XM, Ye LY, Huang J. [Application of double staining in the study of skeletal development toxicity in rats]. $J$ Health Toxicol. 2004;18(4):249-251. Chinese.

46. Luo C, Ren RN, Hu YH, Chen XM, Ye LY, Huang J. Application of double staining in the study of skeletal development toxicity in rats. $J$ Health Toxicol. 2004;18(4):249-251. Chinese.

47. Cui YQ, Yang LY, Miao AJ. [Application of zebrafish in nanotoxicology: a review]. J Nanjing Univ (Natural Sciences). 2017;53(2):316-325. Chinese [with English abstract].

48. Rocheleau S, Arbour M, Elias M, Sunahara GI, Masson L. Toxicogenomic effects of nano- and bulk- $\mathrm{TiO}_{2}$ particles in the soil nematode Caenorhabditis elegans. Nanotoxicology. 2015;9:502-512.

49. Zhang YL, Wang JX. [Advances in effects of cadium on calcium metabolism and its associated potential mechanisms]. J Environ Health. 2004;21(4):269-271. Chinese [with English abstract].

50. Xu SQ, Bao KG, Shu BH, Yao DC. [Influence of cadmium on cartilage and bone formation induced by bone morphogenetic protein]. Chin J Prev Med. 1997;31(5):292-294. Chinese.

51. Wilson AK, Cerny EA, Smith BD, Wagh A, Bhattacharyya MH. Effects of cadmium on osteoblast formation and activity in vitro. Toxicol Appl Pharmacol. 1996;140(1):451-460.

52. Carlsson L, Lundholm CE. Characterisation of the effects of cadmium on the release of calcium and on the activity of some enzymes from neonatal mouse calvaria in culture. Comp Biochem Physiol C Pharmacol Toxicol Endocrinol. 1996;115(3):251-256.

53. Badakhsh MH, Khamseh ME, Malek M, et al. Impact of maternal zinc status on fetal growth in an Iranian pregnant population. Gynecol Endocrinol. 2011;27(12):1074-1076.

54. Clemente Z, Castro VL, Feitosa LO, et al. Fish exposure to nano- $\mathrm{TiO}_{2}$ under different experimental conditions: methodological aspects for nanoecotoxicology investigations. Sci Total Environ. 2013;463-464: 647-656.

55. Tan C, Wang WX. Modification of metal bioaccumulation and toxicity in Daphnia by titanium dioxide nanoparticles. Environ Pollut. 2014; 186:36-42.

56. Mori T, Tani T, Hanasawa K, Kodama M. Effects of zinc deficiency and corticosterone elevation on bone marrow in rats. Eur Surg Res. 2001; 33(1):92-98.

57. Sorell TL, Graziano JH. Effect of oral cadmium exposure during pregnancy on maternal and fetal zinc metabolism in the rat. Toxicol Appl Pharmacol. 1990;102(3):537-545.

58. Xu MZ, Wang $\mathrm{H}$, Wang Z, et al. Zinc supplementation during pregnancy alleviates cadmium-induced developmental toxicity in mice. Acta Univ Med Anhui. 2012;47(4):425-428.
International Journal of Nanomedicine

\section{Publish your work in this journal}

The International Journal of Nanomedicine is an international, peerreviewed journal focusing on the application of nanotechnology in diagnostics, therapeutics, and drug delivery systems throughout the biomedical field. This journal is indexed on PubMed Central, MedLine, CAS, SciSearch ${ }^{\circledR}$, Current Contents ${ }^{\circledR} /$ Clinical Medicine,

\section{Dovepress}

Journal Citation Reports/Science Edition, EMBase, Scopus and the Elsevier Bibliographic databases. The manuscript management system is completely online and includes a very quick and fair peer-review system, which is all easy to use. Visit http://www.dovepress.com/ testimonials.php to read real quotes from published authors. 